British biotechnology boat comes home

The plan to set up a British biotechnology company, much talked of recently (Nature, 5 June) came into the open this week. A company has been set up with an initial capital of $£ 12$ million, between 40 and 50 per cent of which will be provided by the National Enterprise Board. It is hoped that it can be registered as Celltech, but the formalities had not been completed on Monday.

The managing director will be Mr Gerard Fairtlough, until two years ago joint managing director of Shell UK Limited with responsibility for the $£ 300$ million turnover of the petrochemical part of the enterprise, and who has since then been a division head at the NEB.

Mr Fairtlough said this week that the NEB had been looking at the opportunities in biotechnology since the early autumn of last year, when it commissioned a study of the opportunities, apparently from Professor J D Watson, director of the Cold Spring Harbor Laboratory in the United States. At that stage the NEB had not known that Sir Alf Spinks was working on a report on biotechnology for the Advisory Council on Applied Research and Development (ACARD).

The new company will be jointly owned by the NEB (the largest shareholder) and four commercial partners - the Prudential Assurance Company Limited, the Midland Bank Limited, Finance for Industry and British and Commonwealth Shipping Limited. It is intended that roughly a third of the board of the company should be molecular biologists.

The new company plans to recruit between 50 and 75 people over the next two years. It will not build a laboratory of its own but will use existing premises. The location has not been finally decided, but may well be in Cambridge.

The company has taken trouble to come to good terms with the Medical Research Council, and claims that it has a "framework for collaboration" that will allow it to place contracts with MRC laboratories and to have access to MRC "ideas". The embryo company has also been talking to two other institutions, not openly identified but probably including the Imperial Cancer Research Fund.

$\mathrm{Mr}$ Fairtlough says that particular trouble has been taken to study the ways in which molecular biologists might be involved with the new company. Appreciating that some may wish to make money out of their skill, and that others are offended by the notion, it is planned that the company will make commercial arrangements only with the institutions to which people belong, leaving them to decide how individuals should be paid.

At the outset, the new company will make and sell monoclonal antibodies, but will also explore longer-term projects. It is laid down that the company should make money out of something within two or three years. The phrase "lean and hungry" is much used. The first opportunities will, it is said, be in the field of diagnostic tests.

At the same time, the NEB is anxious that the company should be financially strong enough to tackle "big things". The company will not always seek to market its own products to their ultimate users, but will be content with selling licences for manufacture by others where that seems the best course to follow.

The board of the NEB itself is said to be pleased at having launched its first "constructive project" — since the previous board resigned en bloc last November, the board has been primarily concerned with housekeeping. The fact that the NEB rather than the National Research Development Corporation has become the chief public sponsor of the new

\section{Supreme Court stirs up more fear}

\section{Washington}

Recombinant DNA research is moving from the frying pan to the fire. Last month's decision by the US Supreme Court to permit the patenting of live microorganisms has started a new round of public debate about the conditions under which recombinant DNA research should be carried out.

When the National Institutes of Health formulated safety guidelines in 1976, the main concern was the potential health hazard. Attention is now concentrated on the rights of ownership and control over natural processes.

The Supreme Court ruling has crystallized various areas of concern. Several scientists, for example, have expressed their fears that the decision to allow a patent on a strain of Pseudomonas bacterium, developed by research workers with the General Electric Company by inserting foreign plasmids, could create barriers to the free flow of research ideas. Others disagree, claiming that the requirement to publish details of a patent ensures that the information will be publicly available. And the American Society for Microbiology is sponsoring a meeting in Washington this week to explore such areas of disagreement.

The ASM meeting will debate "the proper role of the patent laws in genetic research and development". Questions to be discussed include that of whether the law should be modified to preclude exclusivity or monopoly over a microorganism; and,more generally, whether the decision is consistent with the objectives of the microbiological and biomedical scientific communities.

Professor Emilio Schaechter, chairman of the committee organizing the ASM meeting, highlights one particular area needing attention, that of how research biotechnology company is not only a sign of its skill but a mark of the disfavour in which the NRDC finds itself with academic scientists in general and those working for the Medical Research Council in particular.

On the question why the present British government may have sanctioned this modest investment, $\mathrm{Mr}$ Fairtlough said that the involvement of private capital had been a necessary condition, given "the way our guidelines have been evolving". $\mathrm{He}$ said that the new company would succeed if it could show that it had a "distinctive competence" and if it combined a hardheaded appraisal of the market with a capacity to make better use of people's talents. He considers that Celltech will be able to establish better relations with academic scientists than companies such as Gènetech and Biogen.

using recombinant DNA techniques should be regulated in the private sector. Although NIH operate a system of voluntary compliance with their safety guidelines, they have no desire to act as a full-blown regulatory agency. NIH are considering delegating most safety decisions to local biohazard committees, and there is concern that the regulatory apparatus may be inadequate.

The Department of Labor's Occupational Safety and Health Administration is already taking steps to define its own role, including setting up a committee to outline voluntary control of the exposure of workers to processes involving recombinant DNA techniques.

Both the closeness of the Supreme Court decision - a five to four majority - and the justices' opinions on both sides provide an open invitation to Congress to look more closely at the patenting question. The four minority justices wrote "it is the role of Congress, not of the court, to broaden or narrow the reach of the patent laws". For the majority, Chief Justice Warren Burger admitted that the court's decision had been reached on a narrow interpretation of present patent law and added that Congress was free to amend the law to exclude from patent protection organisms produced by genetic engineering, or to "craft a statute specifically designed for such living things".

Pope John Paul II warned in an address to Unesco that genetic manipulation might be applied to "ends contradictory to those of humanity"'. Four days after the Supreme Court's decision was announced, religious groups representing Protestant, Catholic and Jewish viewpoints issued a statement which said that the questions raised by genetic engineering - who should control it, who would benefit and 